\title{
Outcomes of Unstable Trochanteric Fractures Treated with Short Proximal Femoral Nail
}

\author{
ABDEL RAHMAN S. HAROUN, M.Sc.; MOHAMED O. RAMADAN, M.D.; OSAMA A. SELEEM, M.D. and \\ OSAMA A. AMIN, M.D.
}

The Department of Orthopedic Surgery, Faculty of Medicine, Tanta University

\begin{abstract}
Background: Hip fractures are considered one of the major health problems in aging populations. These fractures are associated with increased disability and mortality and decreased quality of life. Nowadays, most hip fractures are treated by extramedullary or intramedullary implants, which allow a stable fixation in the majority of cases.
\end{abstract}

Aim of Study: Is to evaluate clinical, radiological and functional outcomes of short proximal femoral nail in treatment of unstable trochanteric femoral fractures.

Patients and Methods: 21 patients with unstable trochanteric fractures underwent fixation with proximal femoral nail, assessment was done using Harris hip score.

Results: 15 patients achieved satisfactory results (seven excellent-eight good), four cases had fair outcome and two cases had poor outcome, one case had deep wound infection that led to backing out of screws and fixation failure.

Conclusion: The proximal femoral nail provides a stable construct for fixation of unstable trochanteric fractures that allows early post-operative weight bearing with minimal incidence of implant related failures.

Key Words: Trochanteric-Proximal femoral nail.

\section{Introduction}

HIP fractures are considered one of the major health problems in aging populations [1]. These fractures are associated with increased disability and mortality and decreased quality of life [2] Early mobilization of patients with these fractures is essential to improve fracture healing, minimize immediate post-operative morbidity, and reduce care costs. One essential requirement for early mobilization is mechanically stable fracture fixation [3] . Nowadays, most hip fractures are treated by extramedullary or intramedullary implants, which allow a stable fixation in the majority of cases [4]

Correspondence to: Dr. Abdel Rahman S. Haroun, E-Mail: haroun.dr@gmail.com
The dynamic hip screw is the most commonly used implant for intertrochanteric femoral fractures [5]. Load bearing in the proximal femur is predominantly through the intact calcar femorale; the lever arm of the laterally placed plate is increased, thus, there is a risk of implant cutout if the calcar is not intact [6]

In biomechanical studies an intramedullary device-compared with a laterally fixed side platedecreases the bending force of the hip joint on the implant by $25-30 \%$. This has advantages especially in elderly patients, in whom the primary treatment goal is early full weight-bearing mobilization [7]

It has been postulated that cephalomedullary nails have an advantage over dynamic hip screw fixation because of the load-bearing axis being closer to the hip joint fulcrum, and also due to less blood loss, minimal tissue dissection, shorter operation time, and faster ambulation after surgery [8].

Objectives: Evaluation clinical, radiological and functional outcomes of short proximal femoral nail in treatment of unstable trochanteric femoral fractures.

\section{Subjects and Methods}

In this prospective study, 21 patients were presented with closed unstable trochanteric fractures, 5 of which were males, 16 were females. Age ranged from 60 to 95 with mean of 72.8 years. Fractures treated in this study were unstable according to Evans classification [9], 18 of them were type Id while only 3 were type II, 18 cases had simple fall, and 3 cases fell the stairs as the causative trauma. They were presented to our academically supervised hospital in the period between September 2017 and July 2018. 
Inclusion criteria were closed unstable pattern of trochanteric fractures, and occurring in adults (after physeal closure). Exclusion criteria were open fractures, pathological fractures other than osteoporosis, pediatric age (before physeal closure), neglected fractures more than 14 days old, patients with proximal femoral deformities and patients suffering other musculoskeletal fractures or were unable to walk prior to the injury.

Antero-posterior and lateral views were obtained to delineate injury, skin traction for the fractured limb was done to stabilize the fracture, reduce pain and preserve limb length and to relax and reduce muscle spasm which acts around the fracture until surgery.

Approval for the study was obtained from the Faculty of Medicine Research Ethics Committee. Full counseling of participants in this research and informed consent was obtained from all patients prior to participation, with full privacy of participants and confidentiality of their data preserved.

\section{Surgical procedure:}

- Systemic broad spectrum antibiotic was given an hour before the operation.

- After induction of anesthesia, the patient was placed supine on a radiolucent orthopedic traction table. The uninjured limb was flexed and abducted at the hip. This position allowed usage of the carm image intensifier positioned between the patient's legs to obtain anteroposterior and true lateral images.

- It is important to ensure that the ipsilateral hip was in an adducted position. To accomplish this, the torso was pushed 10 to 15 degrees to the contralateral side.

- To reduce the fracture, traction was applied in the direction of the length of the extremity. This helped to distract the fragments and regain length.

The second step was internal rotation. Each step was checked with the image intensifier.

- Patients were operated upon in the supine position. Sterilization and draping were done taking into consideration exposure of the greater trochanter and an area approximately $5-6 \mathrm{~cm}$ proximal to it. The image intensifier was checked and a lateral view showing the head and neck of the femur was insured to be feasible before starting the operation. A qualified X-ray technician is essential in order to produce proper images and to save time and reduce radiation exposure.

- The greater trochanter was identified by palpation and an incision of approximately $5 \mathrm{~cm}$ was made proximal to the top of the trochanter. The incision was deepened, through the fascia lata, splitting the abductor muscles for approximately three $\mathrm{cm}$. immediately above the tip of the greater trochanter to expose the tip. Using the finger, the tip of the trochanter was identified and the correct entry point was chosen at the tip of the greater trochanter.

- The entry point should be at the tip of the greater trochanter. If it is very medial (such as in the trochanteric fossa), the curved nail will not go down the shaft properly, with the danger of fracturing the femur. If the tip of the curved awl is placed too far laterally, there is a great danger of fracturing the greater trochanter Fig. (1).
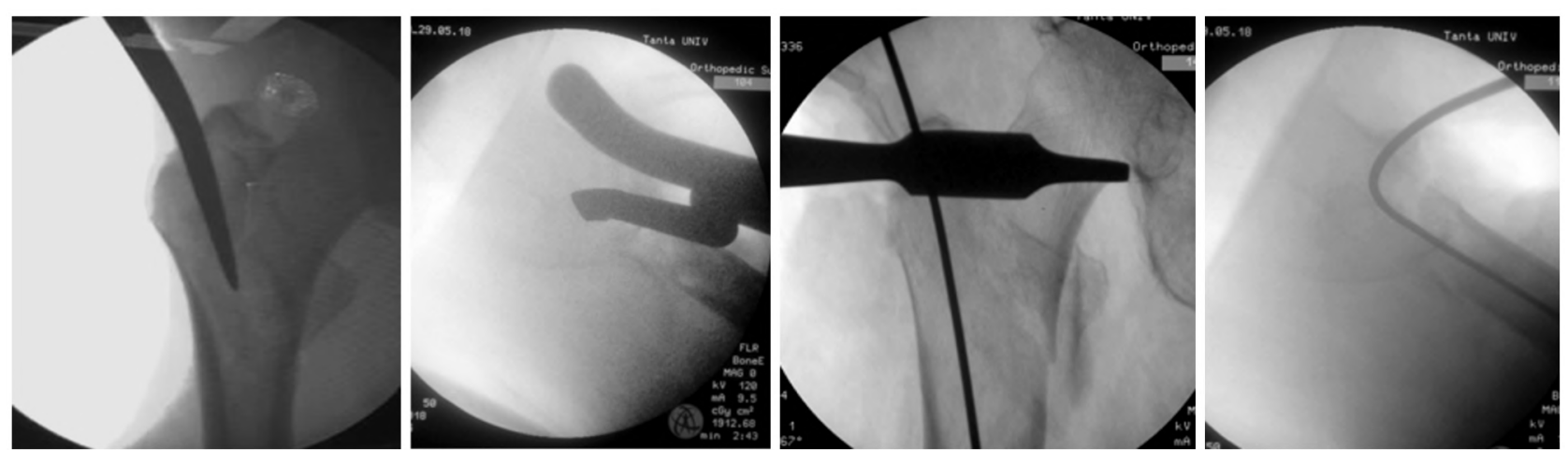

Fig. (1): Position of the entry point and insertion of guide wire.

- In the lateral plane, the awl was placed at the junction of the anterior third and posterior twothirds of the top of the greater trochanter. This was very important to ensure central position of the awl and avoid impinging on or penetrating the anterior or posterior cortex.
When the entry point has been made, the reamer guide wire was placed in position after removing the awl. This guide wire allows the proximal femur to be prepared using flexible power reamers. The reamer guide wire was passed from the entry point in the greater trochanter into the shaft of the femur. 
Flexible reamers were used to ream the shaft of the femur in stages starting from $9 \mathrm{~mm}$ diameter and increasing in $0.5 \mathrm{~mm}$ increments. Reaming was continued until the medullary canal is reamed $1 \mathrm{~mm}$ larger than the intended nail diameter. If the medullary canal is too narrow, it should be reamed to at least $10 \mathrm{~mm}$.

- When preparing the trochanteric region, the reamers were used carefully as this area is composed of cancellous bone and there may be an extension of the primary fracture line. This region must be reamed up to $17 \mathrm{~mm}$ in order to accommodate the proximal part of the nail. The reamers were introduced only to approximately $8 \mathrm{~cm}$, which corresponds to the proximal expanded part of the nail. The lesser trochanter acts as a guide for this distal limit: The reamer should not pass the lower border of the lesser trochanter.

- Maintaining the reduction during reaming was essential to guarantee good reduction on introducing the nail.

- The selected nail, assembled onto the introducer handle, was now inserted under screening by hand. Care was taken to avoid undue force, and a hammer was never used.

- The correct nail insertion depth is reached if the position of the femoral neck screw is just above the calcar in the distal half of the femoral neck. The position of the femoral neck screw can be assessed on the AP view by means of the proximal holes in the nail. Ensure that sufficient space is also available for the hip pin Fig. (2).

- The introducer side-arm and handle gave a guide to the degree of rotation of the nail, so that the lag screw may be placed in the center of the neck on the lateral view.

- It was very important before proceeding further to check that the jig handle and the nail holding blot are fully tightened. The handle must be supported by the assistant, to prevent its weight from externally rotating the nail, which thus alters the correct anteversion. Next, the soft tissue protector was placed through the proximal hole in the aiming device. It was pushed to the skin, marking the site for a small skin incision, which was developed to the bone. Then the soft tissue protector was pushed through the incision to press firmly against the lateral cortex of the femur. It was impacted gently so that the teeth at its tip bite into the lateral cortex to stabilize the targeting assembly.

- The guide sleeve for the lag screw guide wire was inserted and pushed firmly till the lateral cortex. While inserting the guide wire, correct position was checked by using image intensification both antero-posterior and lateral views. The tip of the wire should be just below the center of the femoral head on the antero-posterior view and central in the lateral view Fig. (2).
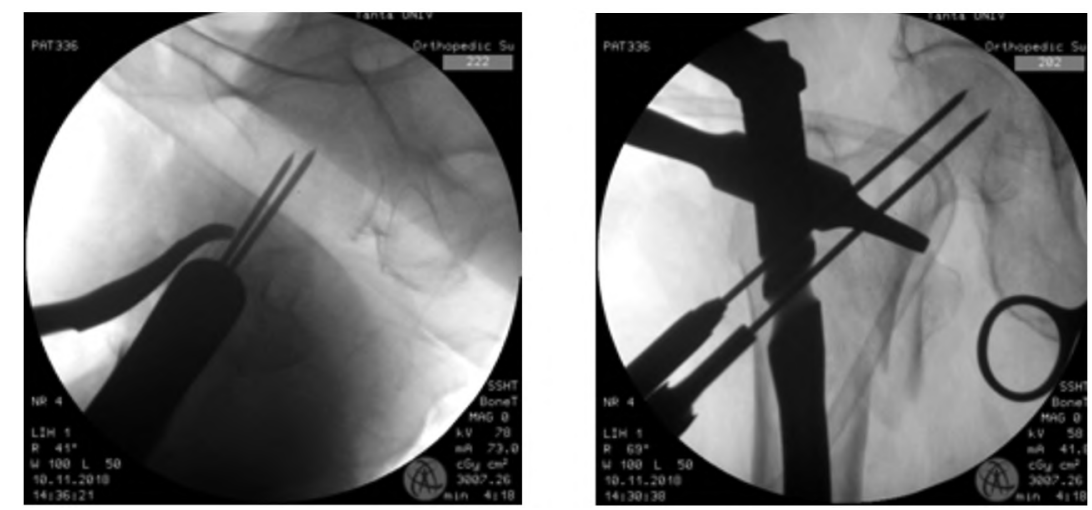

Fig. (2): Checking correct position of the guide wire for the lag screw.

Another guide wire for the hip pin is then inserted in the same manner. The insertion depth of the guide wire should be $10 \mathrm{~mm}$ less than the insertion depth of the femoral neck screw guide wire. This ensures that the hip pin will not take weight load but only fulfill the anti-rotary function.

- After attaining a satisfactory position for the guide wire, the lag screw length was measured using the direct measuring depth gauge. Before starting to measure, the guide sleeve must be firmly pressed against the lateral cortex of the femur. In order to prevent possible rotation of the medial fragment when inserting the femoral neck screw, prior insertion of the hip pin is recommended.

- Advance the $6.5 \mathrm{~mm}$ cannulated drill bit over the $2.8 \mathrm{~mm}$ guide wire of the hip pin. Insert the selected hip pin over the guide wire completely to 
the stop then remove and discard the $2.8 \mathrm{~mm}$ guide wire of the hip pin.

- Guide the direct measuring device over the second $2.8 \mathrm{~mm}$ guide wire through the pink protection sleeve until it touches the bone and determine the required length of the femoral neck screw. The correct screw length is indicated on the measuring device and is calculated to end approx. $5 \mathrm{~mm}$ before the tip of the guide wire.

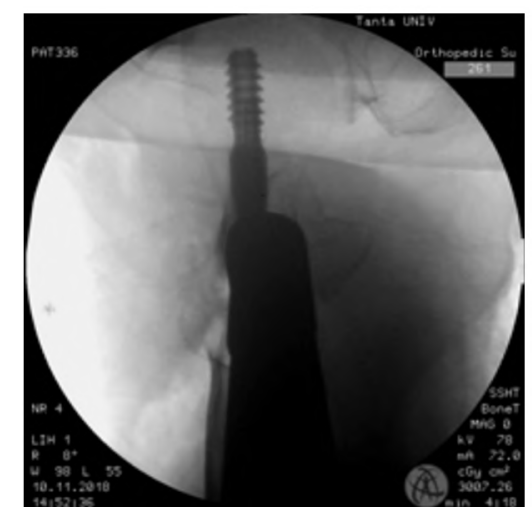

Fig. (3): Application of self tapping neck screw and advancement to the head.

- After checking with the image intensifier the correct position of the lag screw and reduction of the fracture the distal locking screws were inserted through the target device.

\section{Post-operative follow-up:}

Post-operative X-rays were performed after the patient has recovered from anesthesia.

Patients were allowed to sit in bed the next day and begin pendulum exercises of the knee.

Patients were instructed to start weight bearing on the first follow-up after 3 weeks.

Clinical and radiological assessments were done for all patients at 2 weeks, 1 month, 3 months and 6 months searching for any complication of the device or technique of fixation.

\section{Methods for assessment of the results:}

\section{1- Radiologically:}

\section{Early radiological evaluation:}

The quality of reduction based on AP and lateral radiographs was evaluated on the basis of displacement and angulation, and categorized as good, acceptable, or poor. A reduction meets the displacement criteria if there is less than $4 \mathrm{~mm}$ of displacement on either the AP or lateral X-ray. The angulation criteria are met if the neck shaft angulation is normal or slightly valgus $\left(130-150^{\circ}\right)$ and there is less than 20 degrees of angulation on the lateral
- Advance $11 \mathrm{~mm}$ reamer over the $2.8 \mathrm{~mm}$ guide wire. Drill until the stop. Further drilling is prevented by the fixation sleeve. Tapping is not required due to the self-tapping tip of the femoral neck screw.

- The lag of the appropriate length was then passed through the guide sleeve, over the guide wire and threaded up to the subchondral part of the head Fig. (3).

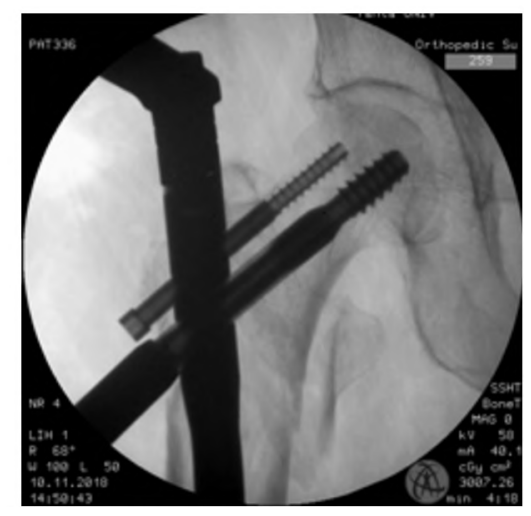

X-ray. A reduction was categorized as good if it meets both criteria, acceptable if it meets one criterion and poor if it meets neither criterion.

The position of the implant was graded as optimal if the neck screw was placed into the center of the neck on a lateral view and lower half on an AP view with a tip apex distance less than $25 \mathrm{~mm}$ and as suboptimal if the neck screw was not placed into the center of the neck on a lateral view or lower half on an AP view or if the tip apex distance was more than $25 \mathrm{~mm}$.

\section{Late radiological evaluation:}

Evaluating signs of union, implant failure and complications such as femoral fractures Fig. (4).
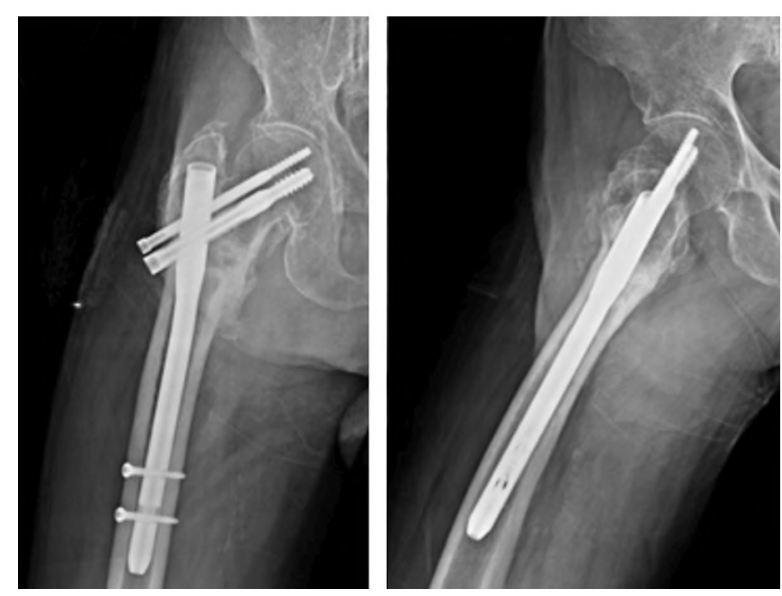

Fig. (4): 6 months follow-up showing union with no complications. 


\section{2- Clinically:}

Data collection and analysis of outcome was completed based on Harris hip score (10) for hip pathology.

\section{Results}

Follow-up period ranged from 6 to 14 months with a mean of 9.58 months and standard deviation 1.75 months. According to Harris hip score (58), the clinical results were graded with the excellent score being: $90-100$, good: $80-89$, fair: $70-79$, and poor $<70$ points. Fifteen patients achieved satisfactory results (seven excellent and eight good) representing $71.4 \%$ of the cases, four cases $(19 \%)$ had fair, and two (9.6\%) had poor outcome based on the before-mentioned Harris hip score.

Nineteen patients had good postoperative reduction; fifteen of them scored satisfactory end result while four achieved fair results. One patient had acceptable post-operative reduction and one had poor post-operative reduction and both patients

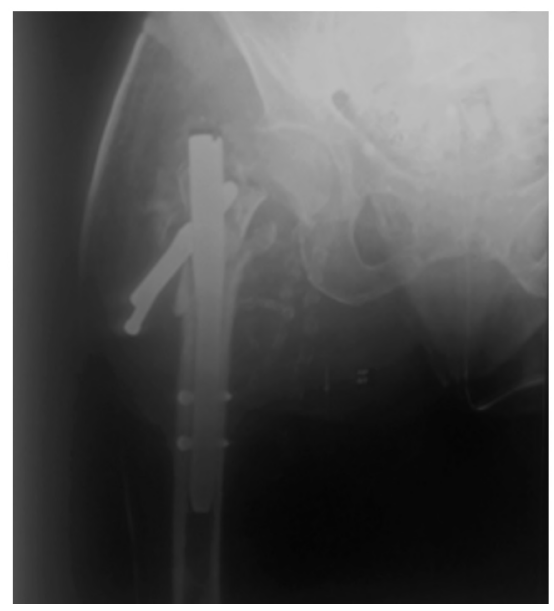

Fig. (5): Failure of fixation after deep infection.

\section{Discussion}

Trochanteric fractures of the femur constitutes a common pathology in elderly patients, the predicted increase in the age of the population and the associated increase in the fractures of the proximal femur have motivated researchers to improve treatment methods $[\mathbf{1 , 2}]$.

The high incidence of varus malunion and the complications of prolonged bed rest have led orthopedists to abandon the conservative treatment of intertrochanteric fractures in favor of internal fixation that reduces morbidity and mortality by permitting early mobilization and rehabilitation $[3,11]$. ended with poor clinical results. Side and sex had no influence on the final clinical outcome, nor did the mode of trauma, type of fracture and method of reduction. However, age, diabetes and postoperative reduction was found to have a significant influence on the final outcome $p$-values (0.032806), $(0.002282)$ and $(0.001835)$ respectively.

Complications: In this study there were three cases with post-operative complications.

There was only one case of deep infection encountered, the patient was diabetic and it resulted in failure of the fixation Fig. (5), loosening and backing out of the proximal screws by the second month the screws were completely out of the nail. The patient underwent surgical debridement and removal of the nail and application of a hip spacer. There was one case of superficial infection, inflamed wound edges was noticed on the first followup, the wound improved after switching to stronger antibiotics. There was one case of delayed union, as union was complete after 7 months.

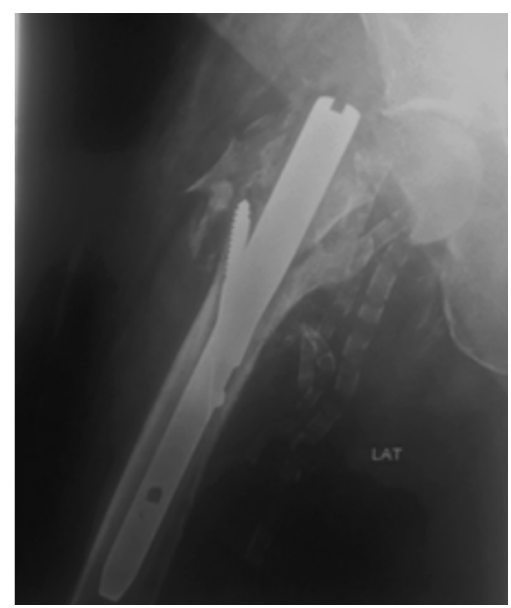

The cephalomedullary nail is a device that was introduced to solve the fixation problems of intertrochanteric fractures. The nail is based on the idea of Küntscher nail and it combines the principles and advantages of the compression hip screw and interlocking nails [12]

In this study, 21 patients with unstable trochanteric fractures were treated using the short proximal femoral nail; 18 were type Id and 3 were type II according to Evans classification [9]. The functional outcome of these cases was assessed by the Harris hip score [10] after a minimum of 6 months post-operative follow-up.

Fifteen patients achieving satisfactory results (7 excellent and 8 good) with a percentage of 
$71.4 \%$ and 6 patients achieving non satisfactory results (4 fair and 2 poor). This result was found to be better than Yllianakis et al., [13] with only $60 \%$ of patients with favorable outcome. On the other hand it was inferior to those reported by Alyassari et al., [14] with 78\% favorable outcome and Gadegone et al., [15] who reported 90\% favorable outcome, although it is worth mentioning that Yllianakis and Al-yassari used Salvati Wilson score [16] while Gadegone used Kyle score [17], thus, comparing the results would not be accurate. As the Kyle score only covers 3 categories (pain, limping and range of motion), while Salvati Wilson covers 4 (pain, walking, function and power with motion). On the other hand Harris score subcategorizes the gait into limping, using of aids and distance and subcategorizes function into using stairs, setting and capability of using public transportation. For example, revising our results withthe much simpler-Kyle score we would find 18 cases with favorable outcome (85.7\%) and only 3 cases with unfavorable outcome (14.3\%).

The ages of the patients in this study ranged from 63 to 95 with a mean of 72.8 years, which conforms to the mean age reported by Yllianakis et al., [13] who reported mean age of 72 and Boldin et al., [18] who reported mean age of 73 .

Age was a significant factor in determining the final outcome in our study as $86.6 \%$ of patients below the age of 76 had satisfactory results, while only $33.3 \%$ of patients above the age of 76 had satisfactory results. Although we did not find evidence of that in the literature, there was correlation between age and early death rates in hip fracture patients as reported by Baudoin et al., and Petitti et al., [19,20]

In this study, males were 6 cases, and females were 15 cases, with a ratio of $(1: 2.5)$, showing female predominance. This was the case in most of the studies [14,18,21,22] except for Gadegone et al., [15] who reported 62 male cases and 38 female cases with a ratio of (1.6:1). This could be due to underlying osteopenia or osteoporosis in the female population with ages above 50 years old. There was no difference in results in relation to sex.

In this study, 18 cases suffered the fracture as a result of simple fall with a percentage of $85.7 \%$ while only 3 patients suffered a relatively higher energy trauma presenting in falling down the stairs with a percentage of $14.3 \%$, this conforms to other studies such as Al-yassari et al., [14] reporting $85.7 \%$ from a simple fall at home and Yllianakis et al., [13] showing predominance of a domestic fall by $67 \%$. There was no difference in results in relation to mechanism of trauma. It was noticed that the lower the age of the patient the higher the energy required to cause the fracture.

Operative time ranged from 80-180 minutes with a mean of 113.8 minutes which is considered quite long comparing to other studies as Simmermacher et al., [21] who reported mean of 68.7 minutes, Fogagnolo et al., [22] who reported 83.4 minutes. This can be explained by the unfamiliarity of our surgeons with the system however, an apparent learning curve could be detected. For example the first case took 150 minutes while the last case took only 90 minutes.

In a study of Christian et al., [23], in 5 patients with reversed oblique intertrochanteric fractures closed fracture reduction was not successful and open reduction was necessary. The latter procedure must, of course, be performed in some unstable proximal femoral fractures although this is not the purpose of minimally invasive devices. Friedl et al., [24] reported open reduction in $52 \%$ of reversed obliquity fractures. In our work we had 3 cases of open reduction 2 of them were reversed obliquity and the other was type Id with failed trials of closed reduction. It was found to have no significance on final clinical outcome.

Butt et al., [25] mentioned operative blood loss to be $40-400 \mathrm{ml}$ (mean $176 \mathrm{ml}$ ) for the gamma nail group while being $80-890 \mathrm{ml}$ (mean $190 \mathrm{ml}$ ) for the DHS group. Andrew et al., [26] reported 22 out of 115 cases who required blood transfusion. In our work, operative blood loss ranged from $50-400 \mathrm{ml}$ with a mean of $186 \mathrm{ml}$ with most of the bleeding resulted from reaming the canal. With the exclusion of cases that required open reduction no blood transfusion was required.

The stability of the construct depends mainly upon the purchase and position of the lag screw in the proximal fragment, both for the Dynamic Hip Screw (DHS) and Proximal Femoral Nail (PFN). Leung et al., [27] recommended that the lag screw be placed in the inferior half of the head and neck in the frontal view and centrally in the lateral view. Boriani et al., [28] reported that the lag screw must always be inserted in the lower portion of the femoral head. This was correlated to the findings that the lag screw did not cut out when placed posterior and inferior close to the medial neck border. Regarding the position of the tip of the lag screw. Baumgaertner et al.) [29] described the position of the lag screw inside the femoral head using the Tip-Apex Distance (TAD). They reported that all lag screws placed inside the femoral head, 
having a TAD of $25 \mathrm{~mm}$ or less showed no cutout and that there was a strong statistical relationship between an increasing TAD and the rate of cutout regardless of all other variables related to the fracture. Baumgaertner and Solberg [30] reported that central and deep screw placement gives optimal fixation and that TAD less than $25 \mathrm{~mm}$ resulted in fewer failures.

Domingo et al., [31] reported 4 cases with cut out screws out of 295 cases and directly linked them to long tip apex distance, while Shimmermacher et al., [21] reported $0.6 \%$ incidence of cut out. In this study, implant position was optimal in all cases, however we encountered one case of screws cut out from loosening of the screws as a result of deep infection.

Another reported complication was migration of the proximal interlocking screw. This may arise from long anti-rotational in shifting of its function from resisting rotation to weight loading and sliding along fracture line that is why it is advised to keep it at least $10 \mathrm{~mm}$ shorter than the lag screw. Migration of the interlocking screws occurs within the nail as these do not secure rigidly within the device itself, and is described in the literature as "Z" effect (proximal migration of the proximal screw) and the "reversed Z" effect (distal migration of the proximal screw) $[\mathbf{1 3 , 1 8}]$. In this study, such complications were not encountered in any patient.

In this study we had 2 cases of local complications, one had superficial infection that responded well to antibiotics and the other had deep infection that required removal of the hardware, debridement and applying a spacer with a total percentage of 9.5\% regarding local complications, this was better than the results reported by Simmermacher et al., [21] with $13 \%$ and Yllianakis et al., [13] with $17 \%$, although it is worth mentioning that both of them did not have any deep infection cases, and their complications were confined to hematoma collection. On the other hand Domingo et al., [31] reported similar results to our study with local complications percentage of $10 \%$ with 29 cases of hematoma and only 1 case of deep infection.

At the time of final follow-up, there were no cases of peri-prosthetic fractures, Simmermacher et al., Gadegone et al., and Boldin et al., [15,18,21] also did not report any. On the other hand Domingo et al., and Fogagnolo et al., [22,31] both reported a single case with femoral fracture that was a result of secondary trauma.

This study, along with Gadegong et al., Boldin et al., Al-Yassari et al., Fogagnolo et al., and
Domingo et al., [14,15,18,22,31] did not have any cases of nail breakage while Yllianakis et al., [13] reported 2 cases after second trauma.

\section{Limitation of the study:}

- Small sample size.

- Noncompliance of the patients with follow-up appointments.

- No other studies were found to assess the clinical outcome using the Harris hip score, however we preferred using the Harris hip score to compare our results with studies of other trochanteric devices used in our university hospitals.

\section{Conclusion:}

The proximal femoral nail provides a stable construct that allows early post-operative weight bearing with minimal to negligible incidence of implant related failures with best outcomes achieved with good postoperative reduction of the fracture.

\section{References}

1- COOPER C., CAMPION G. and MELTON L.J.I.I.I.: Hip fractures in the elderly: A world-wide projection. Osteoporos. Int., 2: 285-9, 1992.

2- WILLIG R., KEINANEN-KIUKAANIEMI S. and JALOVAARA P.: Mortality and quality of life after trochanteri chip fracture. Public Health, 115: 323-7, 2001.

3- AUGAT P., MERK J., IGNATIUS A., MARGEVICIUS K., BAUER G., ROSENBAUM D. and CLAES L.: Early, full weight-bearing with flexible fixation delays fracture healing. Clin. Orthop. Relat. Res., 328: 194-202, 1996.

4- REINDL R., HARVEY E.J., BERRY G.K. and RAHME E.: Intramedullary versus extramedullary fixation for unstable intertrochanteric fractures; a prospective randomized controlled trial. J. Bone Joint Surg. Am., 1905$12,2015$.

5- RADFORD P.J., NEEDOFF M. and WEBB J.K.: A prospective randomized comparison of the dynamic hip screw and the gamma locking nail. J. Bone Joint Surg. Br., 75B: 789-93, 1993.

6- KOVAL K.J. and ZUCKERMAN J.D.: In: Bucholz R.W., Heckman J.D., Court-Brown C., (editors). Intertrochantreric fractures. Rockwood \& Green's fractures in adults. 6th ed. Philadelphia: Lippincot Williams and Wilkins, 1793-825, 2006.

7- ANGLEN J.O. and WEINSTEIN J.N.: Nail or plate fixation of intertrochanteric hip fractures: Changing pattern of practice. A review of the American Board of Orthopedic Surgery Database. J. Bone Joint Surg. Am., 90-A: 7007, 2008 .

8- HALDER S.C.: The gamma nail for pertrochanteric fracture. J. bone Joint Surg. Br., 74-B: 340-4, 1992.

9- EVANS E.: The treatment of trochanteric fractures of the femur. J. Bone Joint Surg., 31B: 190-203, 1949. 
10- HARRIS W.H.: Traumatic arthritis of the hip after dislocation and acetabular fractures: Treatment by mold arthroplasty. An end result study using a new method of result evaluation. J. Bone Joint Surg. Am., 51 (4): $737-$ $55,1969$.

11- ZUCKERMAN J.D., SKOVRON M.L., KOVAL K.J., AHARONOFF G. and FRANKEL V.H.: Post-operative complications and mortality associated with operative delay in older patients who have a fracture of the hip. J. Bone Joint Surg., 77: 1551-6, 1995.

12- KIM W.Y., HAN C.H., PARK J.I., et al.: Failure of intertrochanteric fracture fixation with a dynamic hip screw in relation to pre-operative fracture stability and osteoporosis. Int. Orthop., 25 (6): 360-2, 2001.

13- YLLIANAKIS M.T., ANAGOPOULOS A.P., APADOPOULOS A.P., APASIMOS S.P. and OUSAFIRIS K.M.: Treatment of extracapsular hip fractures with the Proximal Femoral Nail (PFN): Long term results in 45 patients. Acta Orthop. Belg., 70: 444-54, 2004.

14- AL-YASSARI G., LANGSTAFF R.J., JONES J.W. and AL-LAMI M.: The AO/ASIF Proximal Femoral Nail (PFN) for the treatment of unstable trochanteric femoral fracture. Injury, 33: 395-9, 2002.

15- GADEGONE W.M. and SALPHALE Y.S.: Short proximal femoral nail fixation for trochanteric fractures. J. Od. Orthop. Surg., 18 (1): 39-44, 2010.

16- SALVATI E.A. and WILSON P.D.: Long-term results of femoral-head replacement. J. Bone Joint Surg. A, 55A: 516-24, 1973.

17- KYLE R.F., GUSTILO R.B. and PREMER R.F.: Analysis of six hundred and twenty-two intertrochanteric hip fractures. J. Bone Joint Surg. Am., 61: 216-21, 1979.

18- BOLDIN C., SEIBERT F., FANKHAUSER F., et al.: The Proximal Femoral Nail (PFN)-a minimal invasive treatment of unstable proximal femoral fractures. A prospective study of 55 patients with a follow-up of 15 months. Acta Orthop. Scand., 74: 53-8, 2003.

19- BAUDOIN C., FARDELLONE P., POTARD V. and SEBERT J.L.: Fractures of the proximal femur in Picardy. France, in 1987. Osteoporosis Int., 3: 43-9, 1993.

20- PETITTI D.B., SIDNEY S.: Hip fracture in women. Clin. Orthop., 246: 150-5, 1989.

21- SIMMERMACHER R.K.J., BOSCH A.M. and WERKEN C. VAN DER: The AO/ASIF-proximal femoral nail (PFN):
A new device for the treatment of unstable proximal femoral fractures. Injury, 30: 2-7, 1999.

22- FOGAGNOLO F., KFURI M. Jr. and PACCOLA C.: Intramedullary fixation of pertrochanteric hip fractures with the short AOASIF proximal femoral nail. Arch. Orthop. Trauma Surg., 124: 31-7, 2004.

23- CHRISTIAN B., FRANZ J.S., FLORIAN F., GEROLF P., WOLFGANG G. and RUDOLF S.: The proximal femoral nail (PFN)-a minimal invasuve treatment of unstable proximal femoral fractures. Acta Orthop. Scand, 74 (1): 53-8, 2003.

24- FRIEDL W., COLOMBO-BENKMANN M. and DOCKTER S.: Gammanagel-osteosynthes per-und subtrochanterer Femurfrakturen. Chirurg., 65: 953-63, 1994.

25- BUTT M.S., KRIKLER S.J., NAFIE S. and ALI M.S.: Comparison of dynamic hip screw and gamma nail: A prospective, randomized, controlled trial. Injury, 26, no. 9: 615-8, 1995.

26- ANDREW M. TAYLOR and CHRIS BOULTON: Reverse oblique intertrochanteric femoral fractures treated with the intramedullary hip screw (IMHS), Vol. 43 (6): 817 21, 2011.

27- LEUNG K.S., SO W.S., SHEN W.Y. and HUI P.W.: Gamma nail and dynamic hip screw for pertrochanteric fractures; a randomized pro-spective study in elderly patients. J. Bone Joint Surg. Br., 74-B: 345-51, 1992.

28- BORIANI S., De IURE F., BETTELLI G., SPECCHIA I., BUNGARO P., MONTANARI G., CAPELLI A., CANELLA P., REGNOLI R. and TRISCARI C.: The results of a multicenter Italian study on the use of the Gamma nail for the treatment of pertrochanteric and subtrochanteric fractures: A review of 1181 cases. Chirurgia Degli Organi De Movimento, 79 (2): 193-203, 1994.

29- BAUMGAERTNER M.R., CURTIN S.L., LINDSKOG D.M. and KEGGI J.M.: The value of tip-apex distance in predicting failure of fixation of peritrochanteric fractures of the hip. J. Bone Joint Surg. Am., 77 (7): 1058-64, 1995.

30- BAUMGAERTNER M.R. and SOLBERG B.D.: Awareness of tip-apex distance reduce failure of fixation of trochanteric fractures of the hip. J. Bone Joint Surg. (Br.), 79 (6): 969-71, 1997.

31- DOMINGO L., CECILIA D., HERRERA A. and RESINES C.: Trochanteric fractures treated with a proximal femoral nail. Int. Orthop., 25: 298-301, 2001. 


\section{نتائج المسمار الفخذى القريب القصير فيى علاج الكسور

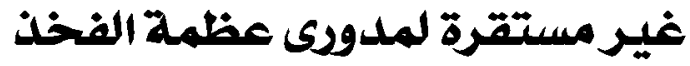

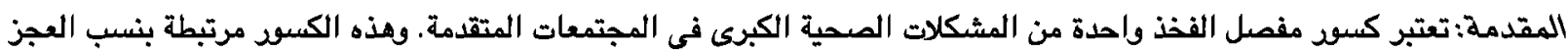

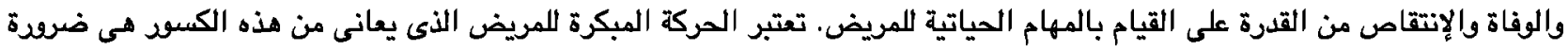

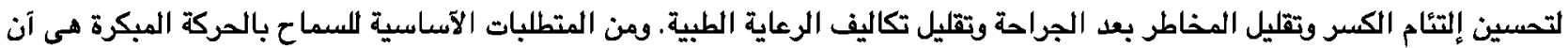

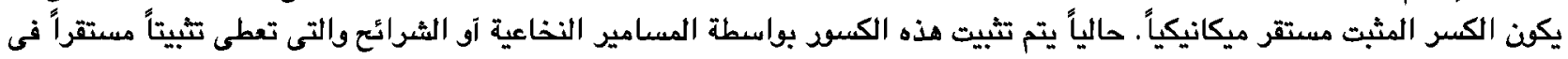
معظم الحالات.

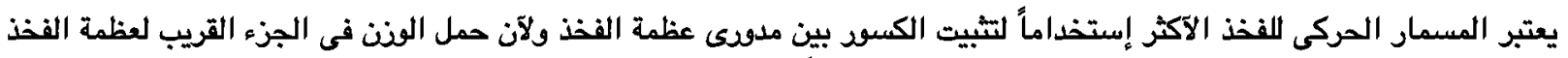

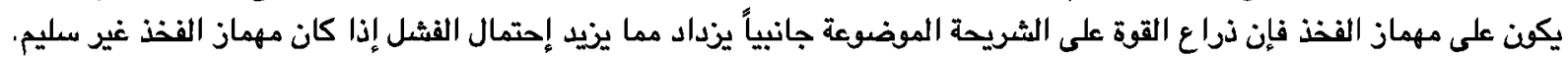

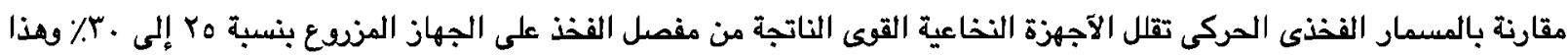

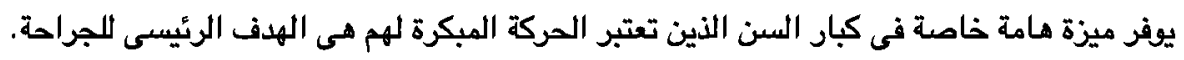

ومن المفترض آن المساهير النخاعية تتفوق على التثييت بواسطة المسامير الحركية اللفذذ لآن إتجاه قوة الوزن يكن آقرب لنقطة إرتكاز مفصل الفخذ علاوة على قلة الدم المفقود في الجراحة مع صغر الفئ الفتح الجراحى وقصر وقت الجراحة.

الهدف من البحث: إن الهدف من هذا البحث هو تقييم نتائج المسمار الفخذى القريب القصير فى علاج الكسود غير مستقرة لمدورى عظمة

المرضى وطرق البحث: إشتمل هذا البحث على إحدى وعشرين حالة من المصابين بالكسود الغير مستقرة لمدودى عظمة الفخذ والذين

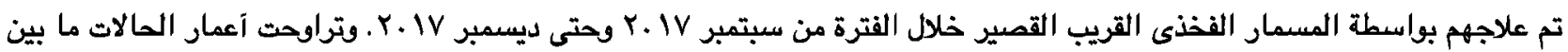

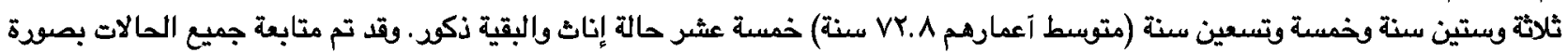
دوية إكلينيكياً وعن طريق الآثعة لمدة ستة آشهر على الآقل.

تائج البحث وتحليلها: تم تقييم النتائج الإكلينيكية لهذه الدراسة وفقاً لمعيار هاريس الفخذى الخاص بتقييم وظائف مفمل الفذذ الصركية والوظيفية.

كما تم تقييم الهالات عن طرق الآشعة السينية الدوية لتقييم وضع الكسر ودرجة إلتئامه وتقييم حدوث مضاعفات من المسمار آو فشل فى التبييت.

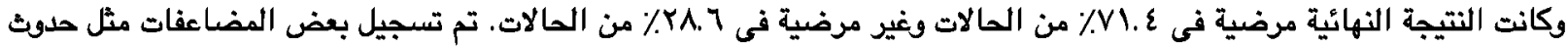

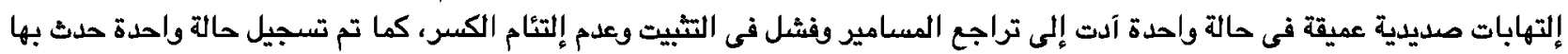

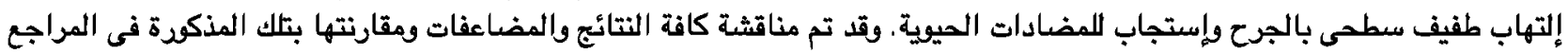
والآبحاث والمجلات العلمية. الإستتاجات:

من وقائع النتائج السابقة يمكنتا إستتناج الآتى: • آن تثبيت الكسود الغير مستقرة لمدوىى عظمة الفخذ بواسطة المسمار الفخذى القريب القصير هى عملية آمنة ولها نسبة نجاح مرتفعة. •رد الكسر إلى وضع قريب من الوضع التشريحى يسهم بشكل آساسى فى الحصول على نتائج مرضية.

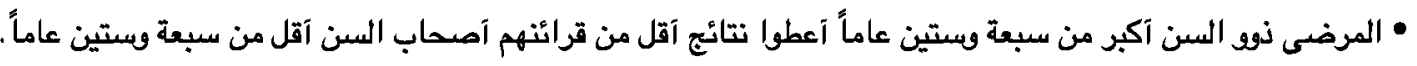
• اللجوء للرد المفترح للكسر لا يؤثر سلباً على النتيجة النهائية الحالة. 